\title{
ALCOOLISMO E TRABALHO - VOZES DE CRIMINÓLOGOS (SÃO PAULO E RIO DE JANEIRO, 1880/1920)
}

\author{
João Batista Mazzieiro \\ Faculdade de Economia e Administração - PUC/SP
}

\begin{abstract}
RESUMO: Este artigo procura compreender o papel econômico, social e político do alcoolismo através de sua caracterização por criminólogos e autoridades da Justiça e da Polícia de São Paulo e Rio de Janeiro entre 1880 e 1920 . Ele caracteriza o alcoólatra como agente em contraposição ao trabalho, que negava o mundo da fábrica ou da fazenda e escolhia o bar, privilegiando no cotidiano o lazer e a semi-consciência, ao invés da hierarquia e da disciplina do mundo do trabalho.
\end{abstract}

PALAVRAS-CHAVE: Alcoolismo, São Paulo, Rio de Janeiro, Brasil, Industrialização.

ABSTRACT: This article discusses the economic, social and political role of alcoholism in São Paulo and Rio de Janeiro in the period of 1880 to 1920. It examines the discourses of criminologists and different Justice and Police authorities about alcoholism in those years and suggests to look at the alcoholic as an agent who instead of industrial and rural labour, choose the pub, rejecting hirarchical and disciplinary rules of world labour.

KEYWORDS: Alcoholism, São Paulo, Rio de Janeiro, Brazil, Industrialization.

"E hoje, ao ver-me na miséria, tudo vejo, então." (Vicente Celestino, O Ébrio)

\section{O Estigma}

O alcoolismo foi encarado pelo saber científico e pela polícia como perigo social ou doença mental. Em ambos os casos, consideravam-se necessários contro- le e repressão. A Teoria da Defesa Social criminalizou o alcoólatra, a Psiquiatria alegou procurar curá-lo: o ébrio era detido pela polícia ou encaminhado para um 
asilo, sendo-lhe reservado um lugar numa instituição de seqüestro - cadeia ou hospício.

Segundo Evaristo de Moraes, importante criminólogo brasileiro do início do século XX,

"o alcoolismo é, antes de tudo, produto da atual desorganização social-econômica e da imoralidade individual, esta resultante dos efeitos da educação e da dissolução da família. Cumpre, portanto, agir sobre as condições existenciais da sociedade e sobre o espírito dos indivíduos". (MORAES, 1921, p.87).

Ele associou a desordem social e econômica à moral. Dessa forma, aquilo que o capitalismo provocava em termos de condições de vida e de trabalho na classe trabalhadora, levando-a ao alcoolismo como forma de sobrevida, era igualado à moralidade dessa classe. O proletariado era visto como imoral e o alcoolismo colocado como comportamento "sujo", sendo ainda o "pecado" de alguns indivíduos. Finalmente, era a falta de educação desses assalariados e a negação que faziam da família nos moldes burgueses que criavam o crime do alcoolismo. Todo modo de vida insubmisso, portanto, devia ser reprimido.

Os criminólogos viam o uso de aguardente como "efeito da miséria": os trabalhadores não recebiam o necessário para a sua sobrevivência e, por isto, recorriam ao consumo do álcool. Afirmaram alguns ser difícil distinguir se a miséria levava ao alcoolismo ou vice-versa. Entretanto, segundo Jaquet, vários bons operários eram conduzidos ao vício pelo pauperismo que,

"com todas suas consequências - alimentação insuficiente, habitação malsã, desordem e sujidade do lar doméstico - conduz de maneira quase irresistível, os homens para as casas de bebidas, onde eles encontram momentaneamente, o esquecimento dos seus males e das suas misérias".

O hábito de beber, nessa perspectiva, estragava os trabalhadores, levando-os à miséria, bem como "a estupidez, a preguiça e a ignorância" (MORAES, 1921, p. 97-98).
A miséria não era vista como uma condição sócio-econômica da classe trabalhadora e sim na condição de coisa má, quase um pecado resultante do desregramento moral. Dessa forma, era o lar "sujo", em desordem e promíscuo que levava o trabalhador para o bar. Daí, o entendimento de que esse trabalhador, se não fosse estúpido, preguiçoso ou ignorante, seria alcoólatra. Os valores da classe trabalhadora, portanto, estavam em julgamento e não sua condição de vida e lazer. O botequim nunca era visto como um legítimo espaço de lazer desses indivíduos mas sim como mundo de sua perdição, de seu desregramento.

É impossível estudar as cidades a partir do século XIX sem nelas ver a multidão, distinguindo nesta os “marginais", a plebe não-proletarizada, a ser esquadrinhada, catalogada, classificada e encaminhada para alguma instituição de seqüestro. Nessa perspectiva, a Polícia tinha que controlar o espaço urbano, evidenciando que a visão de ordem e desordem era diferente para a plebe e para aqueles que detinham o poder.

A partir do século XIX, a burguesia procurou controlar o cotidiano dos trabalhadores. Considerava-se que o fluxo de homens precisava ser vigiado. Criminalizava-se a plebe não-proletarizada. Surgia o conceito de "classes perigosas", contrapondo ao proletariado a plebe não-proletarizada, a fim de controlá-la.

A cidade industrial da virada do século "não tolerava pessoas que se negassem à sujeição do trabalho (...) expulsava-as" (BRESCIANI, 1985).

Foi nesse período que no mundo inteiro se generalizou a repressão aos "pequenos crimes, divertimentos populares e todos os tipos de desordem urbana".

A ordem social ameaçada tinha que ser preservada. Daí, considerava-se que os "pequenos crimes" precisavam ser punidos e mesmo trangressões nãocriminosas deviam ser combatidas (STORCH, p.8-9).

Poucos foram os criminólogos que relacionaram a constituição das classes com o poder de coerção do Estado. Em 1906, um criminólogo paulista já defendia essas posições: Henrique Coelho afirmava que a 
força do Estado, "o incremento da sua tarefa de coerção (...) explicam-se por evidentes motivos de ordem financeira”.

Ele dizia ainda que era preciso enquadrar os trabalhadores numa "severa disciplina" para submetê-los ao capital. Coelho relacionava diretamente os fatores econômicos com o desenvolvimento da criminalidade, declarando que "o estado econômico influi quase exclusivamente na prática do maior número de delitos", e mais:

"vemos a criminalidade contemporânea: como a prostituição, a vagabundagem, a mendicidade, o espírito de revolta e de descontentamento, prender-se à estrutura econômica da sociedade atual, aos excessos do capitalismo" (COELHO).

As autoridades policiais brasileiras desenvolveram o conceito de "classes criminais", separadas da classe trabalhadora: eram aqueles que faziam do crime um modo de vida, "criminosos habituais" (GUIMARÃES, p.29-30). O conceito de "classes perigosas" passou a ser usado pelos parlamentares brasileiros quando buscaram formas de "reprimir os miseráveis". Segundo Chalhoub,

"os legisladores brasileiros utilizam o termo 'classes perigosas' como sinônimo de 'classes pobres'. O fato de ser pobre, torna o indivíduo automaticamente perigoso à sociedade. Os pobres são mais ociosos, cheios de vícios, menos moralizados, podendo "rolar até o abismo do crime"” (CHALHOUB, p.48-51).

Para Moraes, o industrialismo, a ocupação coletiva de trabalhadores e o uso de menores e mulheres na produção fabril "desorganizaram o lar e a família do operário”.

Ao voltar do trabalho, ele encontrava um lar sem luz nem ar, os filhos gritando, uma mulher "роисо amável e mais ou menos resignada”, a inexistência de divertimento e "ele iria buscar no botequim e no álcool a ilusão de felicidade" (MORAES, 1921, p. 104-106).
O cotidiano do trabalhador se resumia, nessa ótica, ao mundo da fábrica e do lar sadio.

De acordo com os criminólogos, o bêbado era sempre um perigo social, prestes a praticar um ato delinqüente, constituindo "para os que o cercam, para a ordem e para a segurança pública perigo permanente".

Além disto, pela sugestão ou imitação, ele levava ao mesmo mal outras pessoas de ânimo fraco.

No Congresso Anti-Alcoólico de 1894, chegouse à conclusão de que a repressão aos alcoólatras se tratava de legítima defesa da sociedade. No Congresso Penitenciário Internacional, três anos, depois concluíu-se que

"os perigos do alcoolismo, no ponto de vista da criminalidade, da miséria, do parasitismo, de degeneração física e moral da descendência do alcoólico, são tão horríveis, que não se pode nutrir a menor dúvida acerca da legítima defesa da sociedade" (MORAES, 1921, p. 117-121).

O alcoolismo e outras questões, desta forma, eram vistos como fazendo parte da questão social, "caso de polícia”. Os ébrios eram, portanto, julgados tão perigosos quanto os anarquistas, um perigo para a ordem pública, devendo o aparelho policial dar conta deles.

Evaristo de Moraes, no início da década de '20, afirmou que a situação no Brasil, quanto ao perigo alcoólico, não diferia da de outros países,

"especialmente nas nossas cidades populosas, fortemente agitadas pelo movimento industrial e pelo vaivém imigratório, o veneno moderno produz suas piores consequências, apavorando quantos ainda se preocupam com o bem estar da coletividade e com o futuro do país".

Principalmente no Rio de Janeiro, na capital e no interior de São Paulo, a polícia reprimia crimes considerados deploráveis em função da ação do álcool. (MORAES, 1921, p.124). Uma das "pragas"a serem controladas com o desenvolvimento urbano, portanto, era o alcoolismo, especialmente pensando que, 
nesse momento, estava em formação o mercado de trabalho assalariado e ocorria a imigração em massa.

Em contrapartida, julgava-se preciso criar nos despossuídos o gosto pelo trabalho, sendo o alcoolismo uma forma de sua negação. O alcoólatra tornava-se um improdutivo, sendo necessário defender-se dele e recuperá-lo para o trabalho.

Moraes caracterizou "o alcoólico, doente, privado de vontade, escravo de sua paixão, prestes a cometer todos os crimes".

Nessa perspectiva, seus "centros moderados" não funcionavam direito, exigindo que a vontade social exercesse sobre eles a "disciplina da razão e do bem estar social” (MORAES, 1921, p.118-119).

Tratava-se, portanto, de disciplinarizar a plebe não-proletarizada e aqueles trabalhadores que se insubordinavam através do alcoolismo.

Os criminólogos afirmavam que a embriaguez era uma doença psíquica, cujo elemento fundamental se constituía num verdadeiro deslocamento com dispersão do Eu pensante e consciente, sobretudo do Eu encarregado dos controles, das ratificações, dos juízos e, portanto, das determinações (MORAES, s/d, p.29). Tal doença significava, então, perda dos controles, das determinações, das regras econômicas, sociais, políticas, sexuais, etc.

Evaristo de Moraes via a existência de uma embriaguez fisiológica e patológica. A primeira significava o uso exagerado do tóxico por parte de um indivíduo normal e a segunda, a utilização de pequena dose por um nevropata. Junto ao uso do álcool, veio a consideração da loucura ou sanidade. Já foi feita aí a discriminação da normalidade, sendo normais e nevropatas classificados dentro do alcoolismo agudo. O alcoolismo crônico ocorria quando se bebia uma nova dose antes que tivesse passado o efeito da anterior (MORAES, s/d-2, p.491-492).

\section{A Estigmatização}

Segundo o Presidente do Tribunal de Justiça de São Paulo de 1893, o álcool provocava degeneração cerebral, produzindo modificações encefálicas, transmitidas hereditariamente, concluindo que

“o alcoólico se não se mata em um acesso de desgosto, vai terminar miseravelmente num asilo, quando não acaba em uma cela ou não tomba sobre a plataforma de um cadafalso" (RPTJ, p. 54).

Franco da Rocha descreveu o caso de um paciente do Juquery que cometeu crime em Franca, sendo considerado dipsomaníaco, absolvido, porém internado. Curado, voltou a Franca e reiniciou-se no uso de bebida, que o levou ao assassinato de um velho, sendo novamente internado no Hospício (MORAES, 1921, p.126-129).

Havia, segundo o discurso médico, três estágios da embriaguez. No primeiro, existia uma certa exaltação intelectual e física, certo bem-estar, amabilidade, narração um pouco incoerente, palavras indiscretas mas consciência perfeita. No segundo, a imaginação decrescia até extinguir-se, a voz chegava à turbulência, os sentidos se obliteravam, a pronúncia se embaraçava, aumentava a dissociação de idéias, a vontade paralizava-se, a paixão se inflamava, " $O$ perigo é iminente, o homem é assimilável, neste momento, ao maníaco e tão perigoso, para si mesmo, como para outrem".

O terceiro estágio era do sono profundo, quando o indivíduo tornava-se incapaz de distinguir o bem ou o mal, transformando-se num animal grosseiro (MORAES, s/d-1, p.13-16).

Na primeira fase da embriaguez, "que é da embriaguez incipiente, ou talvez melhor, de pródomos da embriaguez, os indivíduos têm a integridade e o domínio de seus sentidos, tem consciência de seus atos e são, portanto, responsáveis por eles, também em geral não os praticam violentos e agressivos". 
No segundo período, "é a embriaguez confirmada, neste sentido eles não têm consciência ou pelo menos o domínio inteiro de seus atos, não alcançam as suas consequências e não podem, portanto, carregar todo o peso de sua responsabilidade: são uma espécie de loucos".

O terceiro período era a embriaguez tóxica, "neste estado, eles são em geral inofensivos” (LIMA, p. 265-272).

O Procurador Geral do Estado de São Paulo, Cândido Motta, em 1893 afirmou que

“a simples animação produzida pelas primeiras ingestões do álcool, não é de natureza tal a atuar nas faculdades intelectuais ou volitivas do indivíduo, pervertendo-as. O mesmo não se dá no segundo período da evolução tóxica que produz verdadeiras alucinações e faz com que, na opinião de muitos, o indivíduo revele a sua verdadeira tendência" (RPG, p.52).

Procurando definir embriaguez incompleta, Souza Lima afirmou que ela era a passagem da primeira para a segunda fase, quando

“os ébrios são uma espécie de loucos, sem livre arbítrio, sem consciência de seus atos, sem o menor império sobre suas impulsões".

O álcool teria, portanto, uma ação excitante e paralisante e a excitação, para alguns médicos, seria uma ilusão, um engano (MORAES, 1920, p.32).

Nessa perspectiva, cabia à Medicina julgar o estado de saúde mental do criminoso alcoólatra. O médico perito devia examiná-lo no sentido de verificar se existia alguma tara física ou mental e "se essas taras lhe criaram uma personalidade anormal, e se essa maneira de ser particular influi no seu ato" (MORAES, 1920).

A Psiquiatria teve importante papel na análise do alcoolismo. Kraepelin classificou o alcoolismo como agudo ou crônico. O primeiro era o consumo exagerado de bebida por um indivíduo normal (embriaguez fisiológica) ou dose mínima por um nevropata (em- briaguez patológica). $\mathrm{O}$ outro era "o resultado de reiteradas libações, copiosas ou discretas”, sendo cada dose ingerida sem terminar o efeito da outra (MORAES, 1920, p. 7-8). Seguindo o conceito Kraepeliniano de alcoolismo, era o indivíduo que "sem que o seu organismo haja eliminado toda a quantidade, precedente bebida, incorpora nova porção alcoólica”.

Para os freudianos, o alcoolismo era um sintoma, para a Psiquiatria, uma tendência (MANTA, p.50).

De acordo com Cândido Motta, um vício que não merecia “indulgências" era o da embriaguez pois os seus efeitos perniciosos não recaíam apenas sobre o indivíduo e sim sobre toda a sociedade, "comprometendo-lhe o futuro" (RPG, p. 52).

Já Evaristo de Moraes argumentava que "o alcoolismo crônico é, hoje, considerado uma das enfermedades mais graves que afligem a espécie humana", doença "filha do industrialismo" (MORAES, s/d-2, p. 492-494).

A segunda fase da embriaguez foi considerada criminal, exigindo o controle policial. Ainda segundo Moraes, o alcoólico "torna-se agitado, questionador, inquieto” (MORAES, s/d-2, p. 495).

E isso não era permitido à classe destinada à submissão: a ordem pública e a disciplina deviam ser mantidas, a improdutividade do alcoólatra tinha que ser controlada, vigiada e punida e o tipo de vida das "classes perigosas" que fugisse desses parâmetros só podia ser considerado doentio.

Para os criminólogos, o Estado tinha o direito e até mesmo o dever de internar os alcoólatras (como os doentes infecto-contagiosos), principalmente os bêbados habituais (MORAES, 1921, p.78). Aos alcoólatras-loucos, não cabia a repressão penal.

O alcoolismo patológico foi caracterizado pela ingestão constante de bebidas, chegando ao crônico e à loucura ou produzindo desordens mentais e emocionais em indivíduos tarados. A decorrência de crimes desses indivíduos devia ser seu encaminhamen- 
to para "asilo especial para bebedores". Eles eram transformados, portanto, em clientes de clínicas neuropatológicas. Havia uma zona de limite entre o Direito Penal e a Medicina Mental para os anormais, que estavam entre os responsáveis e irresponsáveis (MORAES, 1920, p.24).

Moraes caracterizou uma carreira cumprida pelo bebedor: começava com os primeiros goles na flor da idade, com plena inteligência e liberdade moral; aos poucos, esmigalhava a inteligência e a razão, pervertendo a moral, tornando-se uma criatura mecânica; finalmente, ia parar num hospital, manicômio ou na prisão (MORAES, s/d-1, p. 24).

Os criminólogos ainda analisaram a influência do alcoolismo na "dissolução familiar", provocando divórcios, abandono da prole, etc.. Esses alcoólatras criavam no seio da família desatinos, não mantendo a casa, gastando tudo o que tinham, além de procederem obscenamente e provocarem escândalos (MORAES, 1921, p.125). O lar, com suas regras sociais, devia ser mantido intacto, o que não acontecia com o alcoolismo.

Não é possível negar a violência gerada no cerne do alcoolismo mas ela só pode ser entendida dentro de uma dinâmica de repressão gerada pela própria sociedade. O alcoólatra expressava a violência advinda dessa sociedade como reflexo dela, que criava o alcoolismo e dele sobrevivia. Além disso, é necessário lembrar que a indústria do álcool era uma das mais prósperas na economia brasileira da virada do século XIX para o século XX.

Uma dimensão política da identidade de alcoólatra era não se submeter à exploração, negando a relação de contrato de trabalho. O indivíduo que bebia e trabalhava não era preso por alcoolismo. $\mathrm{O}$ ébrio ou ébrio desordeiro era aquele que não acatava as regras da produção capitalista ou suas normas sociais, políticas e outras. O indivíduo que se encontrava na segunda fase da embriaguez - ou, como os criminólogos a chamavam, fase criminal - era considerado um "perigo social", cabendo, portanto, a "defesa social", isto é, a atuação do estado. O alcoólatra atacava a ordem pública e fazia parte da camada dos despossuídos, que deviam ser controlados, vigiados e punidos.

Segundo Colajani, o capitalismo era "a causa direta da criminalidade".

A maioria dos criminólogos, entretanto, afirmava que o alcoolismo também gerava o crime e, além disso, relacionava a classe trabalhadora com o alcoolismo e a criminalidade. Moraes disse mesmo que eram os pobres, principalmente os operários, os maiores consumidores de bebidas alcoólicas e que

"a falta de educação dessas classes favorece a produção da criminalidade de origem alcoólica, porque, entre eles, não se opõem a ação do álcool à reação da cultura e da educação moral, da tradição familiar e de outros freios inibitórios".

A massa de operários gerava, portanto, a intemperança, o alcoolismo estava relacionado com as aglomerações de trabalhadores, que consumia $80 \%$ da produção alcoólica.

“A classe operária não encontra, na própria educação, a resistência necessária para reagir contra os impulsos, os desfalecimentos da vontade e as solicitações dos instintos. Por isso a criminalidade operária tem sua principal origem no alcoolismo" (MORAES, 1925, p. 102-108).

Na verdade, o que os juristas afirmavam como origem da criminalidade operária era sua educação, sua moral, sua família, como se sua vida associada ao álcool levasse ao crime. Tal vida, então, tinha que ser criminalizada para poder ser controlada e reprimida, pouco importando sua saúde física e mental. Ele não podia beber porque, amoral, não tinha educação nem lar decente. Nessa visão, o proletariado era predisposto ao crime e o alcoolismo "facilitava" a concretização da criminalidade nata. Os valores e principios da classe trabalhadora eram criminalizados, como se essa classe não pudesse exercer seu direito à vida. Julgavase necessário controlar, vigiar e punir os despossuídos e principalmente a plebe não-proletarizada. Negar a 
educação, a moral, a família - ou seja, a ordem burguesa - tinha que ser transformado num crime.

Havia para os criminólogos uma ligação entre o alcoolismo, a criminalidade e a questão social e como no Brasil do final do século XIX e início do XX a questão social era "caso de polícia", o alcoolismo devia ser tratado pela repressão policial. Relacionava-se, desta forma, a repressão à organização política da classe trabalhadora com o seu lazer, o uso de bebidas alcoólicas.

O álcool era visto como um mal social que requeria repressão. O cotidiano operário que via no bar uma forma de descontração era negado, em contraponto a uma forma disciplinada do próprio lazer, que devia ser sadio, enquanto o álcool era considerado maléfico. O álcool, a partir do momento em que era visto como uma forma de negação do trabalho, devia ter atribuída uma cota de crime. A Medicina, o Direito e a Psiquiatria cumpriram o papel de definir uma doença, um crime, uma alienação para penalizar o alcoolismo, visto como uma doença que devia ser tratada, medicalizada e, por fim, punida.

Quem bebia não trabalhava, não produzia a sua subsistência, não vivia por sua própria conta. O alcoólatra era visto como um improdutivo e, por isso, devia ser punido. $O$ álcool não podia ser apreendido como coisa gostosa porque era considerado sempre danoso. A droga era entendida sempre como destruidora. O convívio social do botequim nunca era compreendido pelo seu lado lúdico de lazer, mas sempre pelo ângulo de contato com más companhias, de vagabundagem, de crime. O trabalhador não tinha o direito ao prazer e sim a obrigação de preservar a ordem, a disciplina e, obviamente, o trabalho. $\mathrm{O}$ alcoolismo era percebido como uma doença e devia ser tratado desta forma. Para tanto, o indivíduo devia ser internado e a embriaguez, vista como uma patologia a ser curada. O bêbado era identificado como um desordeiro, mau trabalhador, amoral e, algumas vezes, anarquista. Por não aceitar os valores determinados pela socie- dade, devia ser vigiado, preso, punido, encarcerado e recuperado para o trabalho. Sendo o trabalho dever de todo cidadão e como o alcoólatra negava isto, devia ser reintegrado no mundo do trabalho. Em contrapartida, o mundo do alcoolista era do crime e devia ser penalizado. Para o ébrio e, ainda mais, para o ébrio desordeiro, cabia a prisão, a cadeia, a colônia correcional.

Nesse sentido, era como se o trabalho sempre dignificasse o homem e o alcóol o corrompesse. O trabalhador teria que ser disciplinado, submetido à hierarquia. A disciplina do trabalho não permitia a droga. Tal mundo negava a plebe não-proletarizada.

A negação do trabalho pelo alcoólatra era o ponto básico das ciências jurídica, médica e psiquiátrica, no enquadramento do alcoólatra como criminoso, considerando-se principais delitos não trabalhar, negar a dominação e ser ocioso.

Na perspectiva de Moraes, o alcoolismo era um dos principais fatores da "degeneração da espécie humana", especialmente depois de meados do século XIX. Esse mal também foi julgado profundo no Brasil. O jurista afirmou que a massa popular, o operariado, era o principal atingido pelo perigoso e

"tão temeroso problema. O espetáculo do alcoolismo brasileiro, entretanto, já é de molde a provocar a reação dos intelectuais e principalmente, a dos médicos e educadores".

É importante observar que ligava-se degeneração à classe trabalhadora, o álcool "estragava" o trabalhador, degenerava a raça, corrompia os valores. Por outro lado, o uso do álcool, considerado um mal do século XIX, foi vinculado ao desenvolvimento do próprio capitalismo, que expandiu seu consumo (ENGELS, 1988). Contrapondo-se a essa massa alcoólatra, existia o saber dos criminólogos, intelectuais, médicos e educadores, que deviam regenerar esses criminosos ou, no mínimo, degenerados.

Na concepção dos criminólogos, havia encadeamentos e entrelaçamentos no processo de degeneração individual ou coletivo. Ferri afirmou que 
"na origem dos fenômenos sociais não existe, quase sempre, uma só causa determinante".

Dessa forma, a criminalidade não era vista como resultado exclusivo do alcoolismo (MORAES, 1921, p. 71-98).

Os estudiosos do Direito Penal procuraram caracterizar a responsabilidade criminal dos alcoólicos. Isso se deu em função de uma marginalização dos alcoólatras. A utilização do álcool foi vista numa relação direta com a criminalidade, ou como componente do crime.

Os criminólogos, psiquiatras e médicos afirmaram constantemente a relação entre loucura, criminalidade e alcoolismo, que "marcham sempre a par, em linha correspondente, em seu movimento ascencional”.

$\mathrm{O}$ alcoolismo engendrava ainda, desse ponto de vista, "seitas de visionários e anarquistas, levados a dar curso a seus impulsos sob as formas as mais violentas".

Cândido Motta afirmou que no Brasil, devido às estatísticas rudimentares, não se podia fazer uma análise profunda da relação entre criminalidade e alcoolismo.

“Mas é incontestável que ela não tem sido pequena, não diremos dos grandes crimes, mas nos de segunda ordem. A grande quantidade de ofensas físicas, que se nota diariamente, não raro é filha da embriaguez, que também é a mãe da vagabundagem e mendicidade, que em grande escala existe nesta capital" (MOTTA, 1893, p.54-55).

$\mathrm{Na}$ análise de Moraes, as casas de bebida representavam "empórios de veneno, produtores da criminalidade, da loucura, da prostituição, de todas as degenerações, enfim".

O álcool foi visto como um desencadeador de degenerações, de deformações dos trabalhadores, de desenvolvimento da prostituição (MAZZIEIRO, 1998). Segundo Moraes, "os criminólogos, os sociólogos e os moralistas (ajudados pelas observações dos neuropatologistas, magistrados, homens da polícia, funcionários das prisões e manicômios) não nutriam, a respeito a menor dúvida, deparando no alcoolismo uma causa de que seria efeito a criminalidade” (MORAES, 1921, p. 89-95).

Os diversos ramos da ciência e os indivíduos diretamente ligados à repressão ao crime foram chamados a declarar a criminalidade do alcoolismo.

Para Moraes, foi nas últimas décadas do século XIX e no início do XX que aumentaram a miséria, a loucura, o crime, a vagabundagem, a prostituição e o alcoolismo, sendo que o desenvolvimento da indústria, da ciência e da arte não impediram essa "marcha", que atingia principalmente os adolescentes e até mesmo as crianças (MORAES, 1921, p.95-96).

Não havia, para o mesmo Autor, um "paralelismo absoluto" entre alcoolismo e a criminalidade, sendo o primeiro "concausa" do segundo. Seguindo os passos de Colajanni e Lombroso, Moraes defendeu que existiam outras concausas físicas, sociais e individuais. Dessa forma, “a ação criminogênea do álcool não podia ser a mesma em todos os países" pois estavam incluidos ainda fatores étnicos, de cultura e educação e, principalmente, prevenção e repressão.

Joly afirmou que

"nada impele para o crime irresistivelmente, nem a hereditariedade, nem a ignorância, nem a miséria, nem a vagabundagem, nem a prostituição, nem o alcoolismo. Quando o alcoolismo se junta e se mistura com certas predisposições perigosas, as exacerba”.

O alcoolismo era considerado, portanto, no mínimo, um co-detonador da criminalidade (MORAES, 1921, p.101-103).

O alcoólatra foi incluído nas classes perigosas, tendo que ser controlado e punido pelo Estado. Assim, no fim do século XIX e no início do XX, foi grande a porcentagem de ébrios e ébrios desordeiros presos pela polícia do Estado de São Paulo. Para aqueles que negavam a disciplina e hierarquia do trabalho alienado, julgava-se necessária alguma forma de controle e repressão. Apesar disso, a reincidência era uma 
característica do alcoolismo, mostrando que ele era uma dimensão da vida no capitalismo, sendo falha ou inócua a proposta de recuperação.

De acordo com o Presidente do Tribunal de Justiça de São Paulo, em 1893

"há três períodos de embriaguez, períodos completamente distintos e que se sucedem: o da excitação, o da ebriedade e o comatoso. Nos dois primeiros ela é incompleta, no último é perfeita e exclue toda a responsabilidade. Entre a excitação da primeira fase e da intoxicação alcoólica e as alucinações da segunda há uma diferença tão sensível que levou os psiquiatras a denominarem a esta - fase criminal" (RPTJ, p.52).

Quais os motivos que levaram os psiquiatras a fazerem uma ligação direta entre a utilização do álcool e a criminalidade? O que os conduzia a ligar ebriedade e crime? Por que considerar tal fase criminal?

Para o Chefe de Polícia de São Paulo, em 1892

“os ébrios por costume e os que habitualmente usam armas proibidas, uns em consequência do embrutecimento de suas faculdades cerebrais pelo alcoolismo que os torna inconsciente, outros, por seu irritável caráter, auxiliando a força física com as armas de sua predileção, tornam-se os verdadeiros causadores da maior parte das desordens, turbulências, ofensas físicas, homicídios e tantos outros crimes congêneres, contra os quais são muitas vezes improfícuos todos os corretivos das leis que não sejam as da educação moral e intelectual” (RCP, p.14).

Não se via nenhuma causa social para o alcoolismo, embora ele fosse associado à pobreza. $\mathrm{O}$ alcoolismo era entendido como um pecado que devia ser extirpado da sociedade. Da mesma forma, concluíase que um filho de alcoólatra também o seria, identificando vício e criminalidade como hereditários. Por outro lado, a morte era entendida como última companheira do alcoolismo, vindo rapidamente, de uma forma ou de outra. $\mathrm{O}$ uso da bebida alcoólica não era proibido pois tratava-se de um importante setor de produção mas condenava-se aquele consumidor, que deixava de ser produtivo, transformando-se num in- tegrante da plebe não-proletarizada. Julgava-se que, com o álcool, a sexualidade aflorava e "um afetivo torna-se um sexual", levando ao crime de atentado ao pudor. O violento, por fim, transformava-se em assassino (RPTJ, p.54).

O uso do álcool era visto como uma coisa ruim. Ele não era entendido como algo existente, como droga liberadora.

Também o uso de tóxicos foi relacionado por criminólogos, psiquiatras e médicos à criminalidade. Os principais crimes cometidos pelos toxicômanos estavam ligados à ordem e à moral. Segundo Pernambuco Filho, eram: desacato à autoridade, agressões, escândalos em via pública, assaltos a drogarias, furtos de blocos de receituários, falsificações de documentos e receitas, delitos sexuais, atentado ao pudor, sadismo, pederastia, caftismo. Os crimes mais violentos como roubo davamse nos momentos de "crise de necessidade" e o homicídio no caso de embriaguez, "por delírio persecutório devido a alucinações e para obtenção do veneno" (PERNAMBUCO FILHO, p. 53).

A atuação do Estado no controle e na repressão ao alcoolismo se deu de forma a penalizar a embriaguez dos despossuídos.

Na visão de Foucault, uma das principais funções do sistema penal era criar uma contradição na massa dos despossuidos, a oposição entre plebeus proletarizados e os não-proletarizados. As leis contra os mendigos, ociosos e vagabundos eram feitas no sentido de obrigá-los a aceitar a sua proletarização, com a burguesia impondo ao proletariado

“certas categorias da moral 'universal' que servirão de barreira ideológica entre ela e a plebe não-proletarizada" (FOUCAULT, 1982, p.50-51).

Nessa mesma perspectiva,

“a justiça burguesa sempre funcionou para multiplicar as oposições entre proletários e plebe não-proletarizada. (...) A justiça, tal 
como funciona enquanto aparelho de Estado, só pode ter por função dividir internamente as massas" (FOUCAULT, 1982, p.62-67).

\section{Daí, o sistema penal}

"fazer aparecer aos olhos do proletariado a plebe nãoproletarizada como marginal, perigosa, imoral, ameaçadora para a sociedade inteira", criando uma barreira ideológica entre o proletariado e a plebe não-proletarizada, sendo a prisão seu principal fator" (FOUCAULT, 1981, p.35 e 59).

Chalhoub afirmou que os processos-crime desse período revelavam a preocupação dos agentes policiais e jurídicos "em esquadrinhar, conhecer, dissecar mesmo os aspectos mais recônditos da vida cotidiana”, com "a intenção de controlar, de vigiar, de impor padrões e regras preestabelecidas a todas as esferas da vida” (CHALHOUB, p.32-33).

Entre os criminólogos, existiram diferentes interpretações do alcoolismo como "causa direta e individual do delito". Garraud disse mesmo que

“considerar irresponsável um indivíduo que comete um crime alcoolizado é um prêmio ao alcoolismo, graças ao álcool é cometido mais da metade dos crimes; daí, (...) a repressão dos crimes de origem alcoólica devia ser rigorosa e exemplar".

Um criminólogo brasileiro, em tese de doutoramento sobre o alcoolismo, declarou que a responsabilidade dos criminosos alcoólatras devia ser efetiva, senão crimes da pior espécie ficariam impunes. Além do que, o aumento da criminalidade em função do alcoolismo gerava a necessidade de uma repressão maior. Era necessário, conseqüentemente, reprimir esse "perigo latente para a ordem social”, até mesmo aqueles indivíduos que se encontravam em embriaguez acidental. $\mathrm{O}$ alcoolismo era, pois, visto como um agravante do crime (MORAES, s/d-1, p.33-43).

Os responsáveis pela Justiça paulista no final do século XIX achavam que "se há um vício que não mereça indulgências é esse (o alcoolismo) porque os seus perniciosos efeitos não se circunscrevem aos indivíduos que a ele se entregam: a sua ação estende-se sobre a sociedade em geral, comprometendo-lhe o futuro" (RPTJ, p. 52).

Contra esse "perigo social", considerava-se necessário uma "defesa social” como controle e repressão do Estado.

Citando dois outros Autores, Moraes disse que " $a$ teoria jurídica perde a bússola diante do alcoolismo”.

A solução para o problema jurídico-penal criado pelo alcoolismo teve duas vertentes: baseando o Direito repressivo na responsabilidade moral, como dizia a escola clássica e estava na maioria dos códigos, a sociedade estaria desarmada perante uma série de indivíduos perigosos; apoiando-o na responsabilidade social, facultaria a solução do problema (MORAES, s/d-2, p. 496).

\section{Dividindo a Sociedade do Trabalho}

Na concepção dos criminólogos, conhecidos os fenômenos do alcoolismo agudo e crônico, sabia-se que o homem alcoolizado "perde a consciência dos seus atos, age impulsivamente, determinado por sentimento e por idéias que o álcool desperta e elabora".

Segundo Moraes, a psicologia do bebedor era mórbida e seu cérebro não era normal (MORAES, s/ d-2, p. 496-497).

De acordo com os criminólogos sendo

"perturbadora da integridade física é a embriaguez. Sem dúvida é um dos elementos modificadores, da responsabilidade criminal. A embriaguez aparece na lei positiva brasileira, mediante certas circunstâncias fundamentais, como atenuante em favor dos delinquentes. (...) Sentidos inteiramente embotados, funções cerebrais em perturbação completa, vontade aniquilada, são fenômenos incompativeis com a responsabilidade das práticas cometidas. A culpabilidade em direito (...) supõe no agente inteligência e liberdade, ela portanto se torna impossível no estado de completa perturbação intelectual e moral produzida pela segunda fase do período alcoólico” (LEAL, p.270-274). 
A embriaguez era vista por esses criminólogos como uma das responsáveis por grande número de crimes. Dessa forma, fazia-se necessária uma repressão maior aos alcoólatras. Para Candido Motta, Presidente do Tribunal de Justiça de São Paulo, em 1893,

"um dos defeitos, que nos parece importante da nossa legislação penal é o que diz respeito à embriaguez. (...) principalmente em relação à falta de repressão enérgica que é devida” (RPTJ, p.52).

Manta, por sua vez, propôs uma repressão ao alcoolismo em três níveis. Dado que o alcoolismo era "mundano", uma "inclinação subconsciente" e uma "riqueza nativa”, fazia-se necessário atacá-lo, através da legislação nas três frentes.

"Para o alcoolismo mundano, a lei e a polícia seriam absolutas; para o alcoolismo, escrescência dipsomaníaca, a psicanálise e a reclusão hospitalar seriam fontes e fórmulas terapêticas: para o álcool, riqueza nativa, a baixa taxação exportativa e o álcool de Estado resolveriam o problema - e os poderes públicos oficializariam então a produção alcoólica” (MANTA, p.46).

Os responsáveis pela ordem e administração pública procuraram inicialmente a solução penal para o "mal social" do alcoolismo. Entretanto, de uma forma geral, ela não era a solução, apesar de nunca ser descartada, pois segundo os criminólogos, as penas cruéis não curavam o bêbado e as de curta duração eram perniciosas (MORAES, 1921, p.73-74).

Se a criminalização do alcoolismo não resolvia o problema, era necessária outra forma de controle, propondo-se então o tratamento médico do alcoólatra. Diante da emergência de exercer o controle e poder sobre os doentes da sociedade e uma vez que o alcoolismo não se resolvia com a criminalização, julgava-se urgente a atuação de outra esfera de poder, agora do saber médico ou psiquiátrico, para normalizar esses desviantes.

Na concepção dos criminólogos, quando o indivíduo, conhecendo o efeito "inebriante da bebida, ingere quantidade exagerada e comete crime ele é imputável e responsabilizado criminalmente".

Evaristo de Moraes não concordava com os argumentos dos seguidores de Carrara, que equiparam os criminosos alcoolizados com o alienado mental, "por excesso venéreo ou outros desvios voluntários”.

O último continuava louco, o embriagado voltava ao seu normal, devendo "aproveitar a reação do organismo social contra o seu ato ofensivo" (MORAES, s/d-1, p.81-86).

Uma corrente de criminólogos via no Direito Penal uma forma de defesa social, devendo, portanto, identificar o perigo que o crime acarretava para a sociedade. Dessa forma, não punir os crimes dos alcoólicos seria conceder um prêmio ao alcoolizado que, segundo eles, era responsável por mais da metade dos crimes, exigindo, portanto, uma repressão rigorosa.

Bittencout Berfort, em tese de doutoramento sobre alcoolismo, afirmou que "a responsabilidade criminal nos casos de embriaguez devia ser sempre efetiva e mais ou menos grave",

tendo a impunibilidade de alcoólatras deixado livres "criminosos de pior espécie".

Além disso, "o crescimento espantoso da criminalidade, (tem) por um dos fatores principais o alcoolismo".

Para Garofalo, existia uma diferença entre a embriaguez e alcoolismo crônico que tornava o indivíduo um "delinquente impulsivo"; no caso deste se tornar um criminoso, devia ser internado em asilo especial, ao mesmo tempo hospital e prisão, para ser curado (MORAES, 1920, p.19-21).

As instituições de sequestro eram a principal forma de atuação do Estado sobre os alcoólatras. O alcoolista, se não fosse punido pelo crime que cometeu, devia sê-lo pelo fato de ser alcoólatra. A sociedade, portanto, tinha que se defender de alguma forma desse mal. 
Teóricos da defesa social afirmavam que " $a$ repressão dos crimes de origem alcoólica devia ser rigorosa e exemplar".

Sendo o aumento da criminalidade ligado ao alcoolismo, alegavam que ao se dar a embriaguez como dirimente, contribuía-se

"para a impunidade de verdadeiros culpados, senão de indivíduos cuja liberdade constitue perigo latente para a ordem social” (MORAES, s/d-2, p.501).

Discordando de Garofalo, que via na ação do álcool "um agente revelador do caráter individual, uma exteriorização forçada de sentimentos e tendências preexistentes".

Evaristo de Moraes afirmava que em cada indivíduo o álcool atuava de uma forma. Defendendo a individualização da pena, ele dizia ser

"preciso estudar cada caso, por maneira a afirmar verdadeiro diagnóstico criminal, determinativo de segura terapia" (MORAES, 1920, p.23).

Segundo Florian, "a embriaguez apresenta manifestações diferentes, conforme os caracteres das pessoas".

Por isso, era necessário estudar caso por caso (MORAES, s/d-2, p.503). No caso do indivíduo que tinha conhecimento dos efeitos inebriantes da bebida e se excedia na quantidade ingerida, cometendo crime, devia ser imputável e responsabilizado criminalmente, na visão de determinada corrente dos criminólogos.

\footnotetext{
"Sendo voluntária a causa e voluntário o efeito a responsabilidade social do criminoso transparece nítida e inteiramente".
}

A pena inclusive devia ser agravada pois o indivíduo buscou

"força e animação em substância cuja ação conhece" (MORAES, 1920, p.41-42).
O criminoso alcoólatra era visto, portanto, como mais perigoso do que o "normal", sendo necessária uma penalização maior pois na verdade ele cometeu dois crimes, uma vez que o alcoolismo já era visto como um tal.

Para os criminólogos, a embriaguez não devia ser nunca atenuante e sim agravante.

"O estado de alcoolização do criminoso devia ser sempre, indiscutivelmente, razões de agravação penal, e jamais motivo de irresponsabilidade ou atenuações penais. $O$ alcoolista devia ser punido sempre. E à lei compete o direito de ser radical e $a b$ soluta" (MANTA, p.42).

Seguindo os princípios do Congresso Penitenciário de São Petersburgo, entretanto, entendia-se que a embriaguez não devia influir na pena, nem como atenuante nem como agravante, estudando-se cada caso particular (RPG, p.52).

A discussão sobre penalizar ou não os criminosos alcoolizados foi, portanto, constante entre os penalistas. Os criminólogos brasileiros discutiam entre si se a embriaguez completa seria caracterizada no segundo estágio ou no comatoso. Alcântara Machado considerou como dirimente a embriaguez completa, mesmo se fosse preordenada ao delito. Vieira de Araújo também entendeu a embriaguez completa como dirimente. Evaristo de Moraes declarou que, ao homem normal que "ingere álcool e se embriaga acidentalmente", cometendo crime, "não podia absolutamente ser imputado o ato" (MORAES, s/d-1, p.56-79).

Teóricos que, de uma certa maneira, seguiam a escola clássica dela fugiam ao não aceitarem a embriaguez como uma dirimente da criminalidade. Este não foi o caso de Carrara, para quem "seria iníquo derivar a punição de um ente tornado furioso pelo álcool”.

\section{Criminalização e Poder Público}

Alcântara Machado afirmou que nenhuma ação seria punida se aquele que a cometeu estivesse sem 
conciência ou liberdade de seus atos. Nessa perspectiva, a embriaguez era capaz de suprimir consciência e liberdade, sendo, portanto, uma causa minorante ou dirimente (MORAES, s/d-2, p.497-499).

Segundo o médico Souza Lima, a embriaguez incompleta constituía

"uma circunstância atenuante admitida em favor dos criminosos, com a condição de que não fossem acostumados a cometer crimes nesse estado e a embriaguez não seja propositalmente procurada para animá-lo à sua perpetração" (LIMA, p.260).

Do Estado, era cobrado o papel de controlador e repressor desse mal social. Apelou-se para a ciência a fim de curar essa doença. Juristas, moralistas e médicos deviam unir-se para salvar o "organismo social, excessivamente prejudicado pela intoxicação alcoólica”. (MORAES, 1921, p.109).

O Estado procurava agir de outras formas, " $n a$ luta contra o alcoolismo”, principalmente através do fisco, limitando ou reduzindo o número de casas de bebidas embora isso fosse contraditório aos interesses do "industrialismo e do comercialismo".

Em alguns países, buscou-se aumentar os impostos sobre bebidas ou criar taxas extras para as casas de bebida, reconhecendo-se entretanto uma ineficácia para tais medidas (MORAES, 1921, p.75-76).

Evaristo de Moraes afirmou que

“a tolerância, entre nós, no Brasil, vai ao ponto de não haver limitado o número das casas de bebidas, dentro de determinado perímetro, nem se proibido seu estabelecimento nas visinhanças de quartéis, de igrejas, de escolas, de cemitérios, e nas ruas habitadas exclusivamente por meretrizes"

Para ele, era totalmente condenável a existência de quatro tavernas ou botequins numa esquina ou de cinco ou seis num quarteirão e, principalmente, a existência de tendinhas em frente às escolas,

“com a exibição de caixeiras-prostituídas e de cantarolagens indecentes" (MORAES, 1921, p.78-79).
Dentro de uma análise do espaço geográfico da cidade, havia certos locais onde a ocorrência da criminalidade era considerada mais presente,

"Locais em que o ruído de gente tocando sanfona ou violão, explodindo em risadas, altercando em torno do baralho rasgado por um parceiro inconformado, mistura-se ao cheiro da lingüiça, das sardinhas fritas, do álcool, e, às vezes do sangue. (...) As vendas e botequins são um dos centros do lazer masculino, aos quais as mulheres comparecem para outros fins ou em função do lazer dos homens" (FAUSTO, p.120).

A história da cidade foi a seqüência da pobreza, da cólera, da miséria, da tuberculose, "dos contágios epidêmicos, viciosos, criminosos e sediciosos", daí, partindo-se para a criação de instituições higiênicas e de uma "arquitetura urbanística": pardieiros, fábricas, oficinas, bares e cabarés foram alvos da higiene e da política de desaglomeração organizada, sendo a higiene pública uma forma de "extirpar a promiscuidade” (BRESCIANI, 1986, p.31).

Ao se estigmatizar alguns locais como de desordeiros e vadios, buscava-se contrapor ao descrito aquilo que se queria da classe trabalhadora: ser morigerada e produtiva.

A urbanização da cidade de São Paulo no final do século XIX e início do século XX, levou a uma freqüente preocupação dos Chefes de Polícia e dos Secretários de Justiça e Segurança Pública com o aumento da população, principalmente, "de uma população flutuante, que não se pode conhecer" (CRUZ, p.84). A massa humana presente no urbano criava, desse ângulo, uma paisagem "de caos, de turbilhão”. Daí, o olhar ter uma importância decisiva na grande cidade: "A vida cotidiana assume a dimensão de um permanente espetáculo" (BRESCIANI, 1982, p. 10-14).

O resíduo social virava um esgoto a céu aberto. Bêbados, vagabundos, prostitutas, homossexuais, loucos, doentes, presos, enfim, a "escória do mundo" devia dar lugar a uma classe trabalhadora limpa 
e ordeira, além de disciplinada. Considerava-se necessário separar o joio do trigo, o bem do mal, o lodo social precisava ser extirpado, destruído.

Para os criminólogos, a intervenção legislativa do Estado era ineficaz "contra o grande mal social do alcoolismo", sendo no máximo coadjuvantes de campanhas anti-alcoólicas. No Brasil das décadas de '10 e '20, quando foram apresentados na Câmara dos Deputados projetos que de uma certa forma regulamentavam o consumo de álcool, ocorreu o protesto dos produtores, tornando, segundo Evaristo de Moraes, "a ação do Estado é difícil, morosa, acanhada e tardia” (MORAES, 1921, p.86-89).

O Código de 1890, no seu parágrafo 10, artigo 42, considerou a embriaguez incompleta como atenuante, seguindo o Código de 1830. No caso da embriaguez completa, ela podia ser julgada causa de irresponsabilidade penal, tornando-se dirimente da criminalidade prevista no seu parágrafo 4 do artigo 27 , que julgava nãocriminoso "os que se acharem em estado de completa privação de sentido e de inteligência no ato de cometer o crime" (MORAES, sd/1, p. 52-53).

Alcântara Machado dava a embriaguez incompleta como dirimente exceto quando ela fosse procurada como forma de animar a feitura do crime. Vieira de Araújo reconheceu na embriaguez completa circunstâncias dirimentes. Viveiros de Castro afirmou que o parágrafo 4 do artigo 27 do Código compreendia a hipótese de estar o indivíduo em estado de embriaguez no segundo grau (MORAES, s/d-2, p. 505).

Cândido Motta, por sua vez, disse, em 1893, que um dos principais defeitos da legislação penal brasileira se referia à repressão à embriaguez, principalmente pelo fato de ser uma "circunstância que atua poderosamente na etiologia do crime”. Segundo ele, a pena de trinta dias de prisão celular não resolvia a questão.

"Os indivíduos dados a embriaguez não se corrigem com essa breve reclusão e, ao contrário, essa abstinência obrigatória o predispõe a beber com mais avidez” (RPG, p.52-53).
A própria repressão ao alcoólatra desenvolveria o alcoolismo, criando o reincidente.

Moraes tinha uma visão muito clara quanto à repressão ao alcoolismo.

“Cumpre, entretanto, atender aos progressos espantosos do alcoolismo e a necessidade imperiosa de refreá-lo? Diante disto, o legislador não se podia manter indiferente, cabendo-lhe combater todas as manifestações do mal social, pois o fim do Estado consiste em promover e conseguir o progressivo melhoramento físico, moral e econômico da sociedade".

Combater os crimes cometidos em embriaguez fazia parte, portanto, do combate ao alcoolismo, procurando "a defesa da sanidade da raça" (MORAES, s/d-1, p. 87-90).

A repressão do aparelho policial aos crimes cometidos pelos alcoólatras e principalmente à prática do alcoolismo era vista, desta forma, como procedimento "purificador" da raça. Aquele que negasse o trabalho ou cometesse algum crime por estar embriagado tinha que ser punido, principalmente porque o álcool era considerado um "perigo social”, que "estragava" o ser humano.

O saber médico, psiquiátrico e jurídico exercia o seu poder sobre essa parcela da plebe não-proletarizada. O alcoólatra tinha que ser tratado como criminoso e doente. Era o mundo da produção que criava a punição para o alcoolismo. A indústria de bebidas alcoólicas tinha que manter os seus lucros; aquele que, ao beber, se tornasse um improdutivo tinha que ser penalizado. O mundo do ócio era, portanto, criminalizado e considerado doentio. O alcoolismo passava a ser uma doença social, necessitando de um tratamento. Os despossuídos que optavam pela vida do alcoolismo não podiam continuar a dar "mau exemplo" para os trabalhadores que deviam ser responsáveis. O uso do álcool de forma abusiva negava a disciplina e hierarquia de que o trabalho alienado necessitava para o aumento da produtividade. A divisão do trabalho capitalista precisava de trabalhadores com o máximo 
de capacidade de trabalho parcelarizado e para tanto, ele não podia estar embriagado pois nesse estado ficava disperso, indisciplinado, improdutivo.

O Congresso Penitenciário de Paris de 1899 afirmou que o alcoólatra perigoso era um psicopata como qualquer outro e desta forma devia ser tratado, privado de sua liberdade pelo Estado, internado em asilos especiais, tutelado e vigiado pela polícia e outras autoridades, submetidos ainda à abstinência total de bebidas alcoólicas, suprimindo entretanto o caráter de detenção dos asilos (MORAES, 1921, p.119-120).

Ferri propôs os substitutivos penais na repressão ao "perigo oriundo do mal alcoólico", principalmente os asilos especiais onde seriam recolhidos os alcoólatras voluntária ou obrigatoriamente dentro da visão de assistência coativa. (MORAES, 1921, p.109). É interessante observar que o encarceramento dos ébrios era considerado assistencial, tendo a função nítida de controle e repressão sobre a plebe não-proletalizada.

No Congresso Internacional de Paris em 1895, propôs-se a criação de "asilos para alcoólicos, nos quais o trabalho seja intensamente organizado”. Regulamentar-se-ia por lei a entrada de quem sofresse condenações por reincidência por embriaguez e de "bêbados cuja alcoolisação constitua perigo individual ou social”, bem como a saída dos mesmos. Em 1898, em novo Congresso, propôs-se "o tratamento forçado da bebidice e do alcoolismo", internando nos asilos os viciados, "sendo neles retidos pelo tempo que parecer conveniente aos médicos" (MORAES, 1921, p.111-115).

A lei e a medicina deviam agir de forma a solucionar o mal social da bebedice. A criminalização do alcoolismo, assim, levava à necessária atuação do Estado e penalização dos alcoólatras.

Em 1908, foi apresentado na Câmara de Deputados, pelo jurista Mello Mattos, projeto de lei "alterando as penas da embriaguez e criando um asilo de bebedores".

Substituía-se assim a pena de prisão por tratamento em estabelecimentos especiais. Propôs-se a revo- gação do artigo 396 do Código Penal, criando a multa para o fato de se apresentar embriagado e a pena de prisão de três meses a um ano para os bêbados de hábito em estabelecimentos correcionais próprios. Seria ébrio habitual aquele que bebesse periodicamente, perdendo o controle de si e de seus negócios, "tornando-se perigoso para si mesmo e para as pessoas com quem vive e para a ordem pública”.

O projeto, entretanto, não foi aprovado (MORAES, 1921, p.132-134).

Para Evaristo de Moraes, nesses asilos, devia-se receber os voluntários, aqueles para quem a família requeria o internamento, "para evitar atos criminosos ou completa perdição moral", os condenados por três vezes em um ano por contravenção de embriaguez e os absolvidos ou impronunciados por algum delito "com fundamento em moléstia mental resultante do abuso do álcool" (MORAES, 1921, p.135-136).

Segundo Garofalo,

"o alcoolista crônico que se tornar criminoso devia ser internado em asilo especial (ao mesmo tempo hospital e prisão) de onde não sairia enquanto não ficar curado, se isto for possível" (MORAES, s/d-2, p.502).

De acordo com Candido Motta, a pena de trinta dias de prisão celular não curava a moléstia social do alcoolismo. Seguindo o Congresso Penitenciário de São Petersburgo, argumentou que devia-se internar os alcoólatras em asilos, de preferência agrícolas. (RPSP, p. 55) O Congresso Penitenciário de 1905 propôs a criação de detenções especiais para bêbados habituais com regime severo, número limitado de detentos e o emprego deles em trabalho agrícola e industrial, além de ensino moral e tratamento médico. Indicouse ainda a detenção prolongada em asilos especiais para os bêbados curáveis e para os delinquentes alcoólicos, a interdição (MORAES, 1921, p.115-117).

O controle social a ser exercido sobre os despossuídos exigia, portanto, um conhecimento da vida cotidiana da classe trabalhadora na sociedade capitalista. 
Esse controle se dava sobre "todas as esferas da vida, todas as situações possíveis do cotidiano”, desde a disciplinarização do tempo e espaço fabril, até à

"normatização das relações pessoais ou familiares dos trabalhadores, passando, também, pela vigilância contínua do botequim e da rua, espaços consagrados ao lazer popular" (CHALHOUB, p.31).

Julgava-se igualmente necessário normalizar a família, a sexualidade, o casamento e a maternidade. O Alienismo, a Medicina Social, a Engenharia, a Polícia e outros saberes e instituições somaram esforços para a

"edificação de uma cidade higienizada, livre da peste e do perigo, que reproduza em seu interior a imagem vitoriosa da ordem burguesa" (CUNHA, p.15).

O Código Penal de 1890 permitiu a intromissão do saber médico no processo e na definição da pena, quando isentou de responsabilidade aquele que cometesse um crime em estado de privação de sentido e de inteligência. Surgiu daí a figura dos "fronteiriços" entre a razão e a loucura. A contraposição entre louco e preso levava a determinadas situações onde se trocava a pena na prisão por um internamento, que em muitos casos poderia até ser maior do que a própria condenação (FAUSTO, p. 99-102).

\section{Conclusão}

A Criminologia via o bêbado como "perigo soci$a l$ " e o alcoolismo era encarado como doença men- tal pela Psiquiatria. Ao Estado, caberia internar os alcoólatras, criando instituições de seqüestro para eles. O alcoolismo era contraposto a disciplina e hierarquia do trabalho assalariado. Os que usavam bebidas alcoólicas faziam parte das "classes perigosas". Os saberes relacionaram loucura, criminalidade e alcoolismo e o álcool foi visto como um catalizador da criminalidade.

Assumia-se a necessidade de mostrar que a lei era feita dentro da lógica dominante, cabendo ao aparelho de Estado garantir que ela fosse cumprida, permitindo assim o controle e a repressão sobre os despossuídos.

O alcoolismo era entendido como caso de polícia, tal como o movimento social. O uso do álcool foi criminalizado por ser a negação do mundo do trabalho e interpretado enquanto caracterizador da criminalidade.

A Criminologia, a Medicina e, nesta, a Psiquiatria foram saberes que buscaram normalizar os alcóolatras. Cada um daqueles saberes criou uma instituição de seqüestro para os alcóolatras: a cadeia, o hospital e o hospício.

Daí, ser preciso fazer um estudo crítico da Criminologia e apresentá-la como uma ciência enraizada do poder, indo fundo no estudo sobre a Criminologia crítica ou radical para perceber que a conceituação dos criminólogos era influenciada pela dominação. Se o criminólogo deve também ser um historiador (DONNICI, p.59 e 138-139), a Historiografia que busca o estudo da história urbana, da justiça criminal, da polícia, dos tribunais, da prisão e do comportamento criminoso precisa se unir com a Criminologia radical (TAYLOR ET AL., p.127). 


\section{Fontes e Bibliografia Analítica}

BRESCIANI, Maria Stella Martins. Londres e Paris no Século XIX: O Espetáculo da Pobreza. São Paulo: Brasiliense, 1982. "Metrópolis: as Faces do Monstro Urbano". Revista Brasileira de História (Cultura e Cidade). São Paulo: ANPUH/ Marco Zero, 5 (8/9): 38-61, 1985.

"Lógica e Dissonância - Sociedade de Trabalho: Lei, Ciência, Disciplina e Resistência Operária”. Revista Brasileira de História (Sociedade e Trabalho na História). São Paulo: ANPUH/Marco Zero, 11, set/1995, fev/1986.

CHALHOUB, Sidney. Trabalho, Lar e Botequim: o Cotidiano dos Trabalhadores no Rio de Janeiro da Belle Époque. São Paulo: Brasiliense, 1986.

COELHO, Henrique. "O Direito e o Proletariado". São Paulo Judiciário. São Paulo, 38: 67/80, fev 1906.

CRUZ, Heloísa de Faria. Os Trabalhadores em Serviço: Dominação e Resistência - 1900/1920. Dissertação de Mestrado apresentada ao Departamento de História do IFCH/ UNICAMP. Campinas, Mimeografado. 1984. p. 84. (Publicada com o mesmo título por CNPq/Marco Zero, São Paulo, 1991).

CUNHA, Maria Clementina Pereira. O Espelho Do Mundo: Juquery, A História de um Asilo. Rio de Janeiro: Paz e Terra, 1986.

DONNICI, Virgílio Luiz. A Criminalidade no Brasil (Meio Milênio de Repressão). Rio de Janeiro: Forense, 1984.

ENGELS, Friedrich. Situação da Classe trabalhadora na Inglaterra. São Paulo: Global, 1988.

FAUSTO, Boris. Crime e Cotidiano: a Criminalidade em São Paulo (1880-1924). São Paulo: Brasiliense, 1984.

FOUCAULT, Michel. Microfísica do Poder. 3.ed. Rio de Janeiro: Graal, 1982.

. Un Dialog sobre el Poder y Otras Conversaciones. Madrid: Alianza Editorial, 1981.
GUIMARÃES, Alberto Passos. As Classes Perigosas - Banditismo Rural e Urbano. Rio de Janeiro: Graal, s.d. p. 29-30.

LEAL, A. Câmara. "A Embriaguez em Nosso Direito Penal”. São Paulo Judiciário. São Paulo, 125/128, maio/ago 1913.

LIMA, Souza. "Do Estado Mental sob o Ponto de Vista da Responsabilidade Criminal”. Gazeta Judiciária. Ano I, III vol., 1893, set/dez.

MANTA, I. de Neves. O Alcoolismo na Arte e na Psiquiatria. Rio de Janeiro: Flores \& Maud, 1932.

MAZZIEIRO, João Batista. "Sexualidade Criminalizada: Prostituição, Lenocínio e Outros Delitos - São Paulo, 1870/1920". Revista Brasileira de História (Arte e Linguagem). São Paulo: ANPUH/Humanitas, 18 (35): 247/285, 1998.

MORAES, Evaristo de. A Embriaguez e o Alcoolismo Perante o Direito Criminal e a Criminologia. Rio de Janeiro: Jacinto Ribeiro, s/d-1.

"A Embriaguez e a Responsabilidade Penal". Revista de Direito. vol XII, s/d-2.

Problemas de Direito Penal e de Psicologia Criminal. Rio de Janeiro: Leite Ribeiro \& Maurilio, 1920.

Ensaios de Patologia Social. Rio de Janeiro: Livraria e Editora Leite Ribeiro, 1921.

PERNAMBUCO FILHO, P. Venenos Sociais. Rio de Janeiro: Flores \& Maud, 1932.

Relatório do Chefe de Polícia de 1892. São Paulo, 1892. (RCP)

Relatório do Presidente do Tribunal de Justiça de São Paulo. São Paulo, 1893. (RPTJ)

Relatório do Procurador Geral do Estado de São Paulo. São Paulo, 1893. (RPG)

STORCH, Robert D. "O Policiamento do Cotidiano na Cidade Vitoriana". Revista Brasileira de História (Cultura e Cidade). São Paulo: ANPUH/ Marco Zero, 5 (8/9), 1985.

TAYLOR, Ian, et Al. A Criminologia Crítica. Rio de Janeiro: Graal, 1980.

Endereço do Autor: Rua Apinagés, 880 - apto. 01 - Perdizes - São Paulo - SP - Brasil - CEP 05017-000 